\title{
THE CONDITIONS FOR MAJORITARIAN OBLIGATION: MAJORITY RULE AND DELIBERATIVE BODY*
}

\begin{abstract}
PHILIPPE URFALINO ${ }^{\dagger}$
Precisely where a super-individual entity exists or is assumed, outvoting is possible

$(\text { Georg Simmel })^{1}$

Any final verdict, as long as it is conceived as such, will not be entirely detached from everything that preceded it. From the moment the decision is taken, the social life of the community carries with it not merely the decision itself, but also the arguments that preceded it (Chaim Perelman and Lucie Olbrechts-Tyteca) ${ }^{2}$
\end{abstract}

\begin{abstract}
Considering one of Georg Simmel's questions, the article examines what gives an authority to an outnumbering superiority in a situation of a collective decision. Actually there are three conditions in that matter. First, the majority obligation for a collection of individuals' decisions is possible only if this body is a deliberative body that is to say a collective entity but not a mere collection of individuals. Second, the stake of the decision must not challenge the members' liking for this collective entity. Finally, to have a legitimate majority, the aggregation of preferences must be reached after a deliberation, thus stressing there

\footnotetext{
* A French version of this text was published in Raisons politiques, Vol. 53, 1 (2014). Translation from the French by Amy Jacobs.

$\dagger$ Professor at the Ecole des Hautes Etudes en Sciences Sociales, Raymond Aron Center for Political and Sociological Studies, France. Senior Researcher at the National Center of Scientific Research (CNSR).

${ }^{1}$ Georg Simmel, The Phenomenon of Outvoting, in THE SOCIOLOGY OF GEORG SIMMEL (Kurt H. Wolff transl. and ed., 1964), pp. 245.

2 CHAim PeRELMAN \& LuCIE OlBRECHTS-TYTECA, THE NEW RHETORIC: A TREATY OF ARGUMENTATION (J. Wilkenson \& P. Weaver transl., 1969), pp. 58-59.
} 
might have been other preferences. If the preferences are the same or do not result from the deliberative body's deliberation, the collective decision looks like a shared decision, a fair one is wished. The rule of the majority is not relevant any longer.

KEYWORDS: Collective Decision; Deliberation; Majoritarianism; Aggregation of Preferences; Decision-Making.

RESUMO: Considerando uma das questões de Georg Simmel, o artigo examina o que confere autoridade a uma superioridade exorbitante em uma situação de decisão coletiva. De fato, há três condições nesse sentido. Primeiro, a obrigação majoritária de uma coleção de decisões individuais somente é possível se este corpo é um corpo deliberativo, isto é, uma entidade coletiva, mas não a mera coleção de indivíduos. Segundo, o custo da decisão não deve afetar o apreço de seus membros pela entidade coletiva. Finalmente, para haver uma maioria legítima, a agregação de preferências deve ser alcançada após uma deliberação; portanto, enfatizando que outras preferências podem existir. Se as preferências são as mesmas ou não resultam da deliberação de um corpo deliberativo, a decisão coletiva aparenta uma decisão compartilhada, esperando-se que seja uma decisão justa. A regra da maioria não é mais relevante.

PalavRAS-ChAVE: Decisão Coletiva; Deliberação; Majoritarismo; Agregação de Preferências; Tomada de Decisão. 


\section{TABLE OF CONTENTS:}

I. INTRODUCTION .................................................................................65

II. COUNTING AND WEIGHING ...................................................................66

1. Neither sanior pars nor maior pars ..........................................67

2. The majority cannot impact on what unites it to the minority …....................................................................................70

III. THE PLACE OF FAIRNESS.........................................................................73

1. Preferences to satisfy? ..............................................................75

2. The respective weights of contributors ....................................77

IV. IN THE NAME OF A WHOLE.....................................................................81

1. The petition model and the deliberating body........................81

2. Plurality, the whole, and unity ..................................................84

V. REITERATING DECISION-MAKING PROCESSES ..................................89

1. An assembly of equals...............................................................89

2. Numerical power struggle or majoritarian obligation .........92

3. A rational power for opposites..................................................95

VI. CONCLUSION ……………………................................................................98

VII. REFERENCES ..............................................................................................99

VIII.APPENDIX .........................................................................................................102

\section{SUMÁRIO:}

I. INTRODUÇÃO ............................................................................................65

II. CONTANDO E SOPESANDO ......................................................................66

1. Nem sanior pars, nem maior pars...........................................67

2. A maioria não pode impactar no que as une à minoria........70

III. O LUGAR DA JUSTIÇA .............................................................................73

1. Preferências para satisfazer?....................................................75

2. Os respectivos pesos dos colaboradores...................................77

IV. EM NOME DE UM TODO .......................................................................81

1. O modelo de petição e o corpo deliberativo............................81

2. Pluralidade, $\mathrm{o}$ todo e unidade ...................................................84

V. REITERANDO PROCESSOS DE TOMADA DE DECISÃO.............................89

1. Uma assembléia de iguais........................................................89

2. Luta pelo poder numérico ou obrigação majoritária ............92

3. Um poder racional para opostos..............................................95

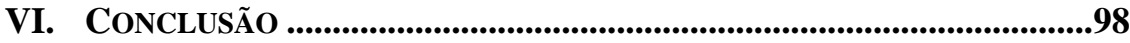

VII. REFERÊNCIAS............................................................................................99

VIII.APÊNDICE .....................................................................................................102 


\section{INTRODUCTION}

To my knowledge, Georg Simmel is the only founding father of sociology to have devoted several pages to the sociological import of the prevalence of majority rule. Those pages figure in the section of his Sociology on domination and subordination. The English title, "The Phenomenon of Outvoting," is consistent with the original German Uberstimmung and clearly indicates Simmel's line of attack: Why should the minority submit to the majority's decision if it is not forced to do so by that majority in the name of the ideal of unanimity? The reason that violence is not needed to make the minority comply, explains Simmel, is "the majority's inner right, which goes beyond the numerical preponderance of votes and the external superiority symbolized by it. The majority appears as the natural representative of the totality. It shares in the significance of its unity, which transcends the mere sum of the component individuals and has something of a super-empirical or mystical note." 3 As Simmel understood it, then, majority rule raises the question of constituting a social whole out of the individuals that make up that whole.

In a recent study of the literature on majority rule, Stéphanie Novak notes that while our knowledge of its mathematical properties and its advantages and drawbacks compared to other decision rules has progressed considerably, the reasons behind the minority's voluntary submission remain mysterious. ${ }^{4}$ Clearly this does not mean that there is something mysterious in the obligation itself, though this does seem to be the sense of some of Simmel's remarks: he never actually answered the question he can be credited with raising. There may actually be no enigma to solve. It is perhaps our usual way of seeing collective decisionmaking and majority rule that makes minority submission seem something of a mystery.

However that may be, Novak's diagnosis is an incentive to return to Simmel's question and examine the conditions of what we might be welladvised to call majoritarian obligation, as majority rule decisions have to be followed not only by those who make up the minority but also those who voted with the majority and who, as Kelsen noted, would certainly feel the burden of that obligation if their opinion were to change.

The question of what conditions majoritarian obligation is not necessarily an external one, it may be raised by the members of a

${ }^{3}$ Georg Simmel, The Phenomenon of Outvoting, in THE SOCIOLOGY OF GEORG SIMMEL (Kurt H. Wolff transl. and ed., 1964), pp. 242.

${ }^{4}$ Stéphanie Novak, Majority Rule, 9 PHILOSOPHY COMPASS 10 (2014), pp. 681-688. 
collective decision-making body themselves. My guiding reference in this study is a remarkable episode in American academic and political history that offered the great historian of the Middle Ages, Ernst Kantorowicz, an opportunity to develop a reasoned critique of majority decisionmaking on the basis of events in his own university. The conditions of majoritarian obligation are likely to stand out more sharply in a context where its validity is contested.

Majority rule is not limited to democratic contexts; it may just as readily be found in an assembly of aristocrats, an intra-institutional committee or political assemblies in non-democratic regimes. The only requirement is that the individuals involved be understood to contribute equally to the decision. On the basis of this observation, we can leave aside the question of the relations between majority rule and democracy, though some of the studies I will be mentioning refer to them. If a sociological examination of collective decision-making can succeed in bringing to light the general conditions of majoritarian obligation, it will be easier to examine the specificities of its usage in democratic contexts.

\section{COUNTING AND WeIGHING}

In 1950, the Board of Regents of the University of California at Berkeley voted by a small majority (12-10) to require professors to take a loyalty oath in which they would swear, among other things, that they were not Communists. Any professors refusing to take the oath would be fired. This collective decision, which should be understood in terms of its Cold War and Korean War context, is of interest here for two reasons: 1) the Board of Regents was able to impose the oath and get 31 opposed teachers terminated on the basis of very small majority that changed from one meeting to the next; 2 ) among the professors who refused to accept the injunction was the great historian of the Middle Ages Ernst Kantorowicz, who actively fought to annul what seemed to him a decision that ran counter to the notion of a university and threatened democracy. In his in-depth analysis of the affair, Kantorowicz not only contested the decision but explained at length that in this particular case majority rule had no inherent legitimate power to impose it. I shall first summarize Kantorowicz's line of argument; then draw some lessons from it that hold for majority rule in general. 


\section{Neither sanior pars nor maior pars}

At the beginning of his text, Kantorowicz considers the Board of Regents' decisions in light of a pair of notions used in church elections in the Middle Ages:

Mediaeval Canon Law has developed a curious theory of evaluating votes, that of the maior vel sanior pars. Usually the majority (maior pars) would decide an issue. A minority, however, had nevertheless some chance to defeat a nonsensical decision if that minority proved to be the "saner part" (sanior pars). The votes, in that case, were not counted but, so to speak, "weighed." They were weighed according to the prestige and authority (auctoritas) of the voter, his intellectual faculties (ratio), his moral qualities (pietas), the purity of his motives (bonus zelus), and the fairness of his judgment (aequitas). Much can be said against this principle; but had it prevailed at the meeting of the Board of Regents of the University of California on August 25, 1950, the group headed by Governor Warren, including Admiral Nimitz and President Sproul, would probably have carried the day by auctoritas as the "saner part." Since, however, votes in a democracy are not weighed but counted, which has its great advantages too, the faction headed by Regent John Francis Neylan decided the issue. Thirty-one professors were ousted by a 12-10 majority, thus reversing the decision of Governor Warren's 10-9 majority in July. Had Admiral Nimitz been present at the August meeting, the majority would have been 12-11; for he wired he would have cast his vote with Governor Warrenas it were, with the "saner part."

The first thing to note is that Kantorowicz's argumentative use of the Medieval categories here can hardly be considered a case of scholar's vanity given the seriousness of the affair, which abolished the tenure, academic freedom, careers and income of a considerable number of professors. Second, it does not seem to me merely a manifestation of Kantorowicz's nostalgia for the Middle Ages and desire to distance

${ }^{5}$ ERNST H. KANTOROWICZ, THE FUNDAMENTAL ISSUE: DOCUMENTS AND MARGINAL NOTES ON THE UNIVERSITY OF CALIFORNIA LOYALTY OATH (1950), pp. 6. Kantorowicz's text and other documents and analyses are available on the website created for the $50^{\text {th }}$ anniversary of the controversy, available at:

$<$ http://sunsite.berkeley.edu/ ucalhist/archives exhibits/loyaltyoath/symposium/kanto rowicz.html.>. See also Alain Boureau's analysis in ALAIN BOUREAU, KANTOROWICZ: STORIES OF A HisTORIAN (S.G. Nichols \& G.M. Spiegel transl., 2001). 
himself from his own time, though there is of course something ironic in his allusive oscillation between the respective merits of the two decision-making methods: "Much can be said against this principle [of sanior pars] ... however, votes in a democracy are not weighed but counted, which has its great advantages too." In fact, he uses the sanior pars notion as a rhetorical device; its features allow him to line up the arguments he will use to discredit the majority group on the Board of Regents: lack of authority, because the most eminent members-Admiral Nimitz; Earl Warren, then Governor of California and future Supreme Court Chief Justice; University President Alfred Sproul-were among those opposed to the oath; lack of rationality, because the Regents on Neylan's side were naive enough to believe that oaths could be used to combat communism and in so believing imperiled the University; impure motives, because the real motive behind the entire affair was to spread irresponsible political propaganda, etc.

However, Kantorowicz's invocation of the sanior pars is also more than a rhetorical device. It implicitly raises an important question: Is numerical superiority enough to legitimately impose such a decision? This implicit inquiry prepares the ground for critiquing the idea that majority rule is endowed with some inherent unconditional validity. Kantorowicz not only explains at length how bad the reasons for and effects of the decision are but also demonstrates that the Board could not take such a decision on the basis of majority rule. Not only was the policy voted by the University's highest, most eminent body a bad one, butand this is why it is of interest here-the way that policy was adopted meant it could not legitimately be imposed.

Kantorowicz bases his argument on two observations. First, the Board of Regents was implacably divided into two nearly equal parts, meaning that the decisions reached during its successive meetings swung back and forth between the choices of the two different sides as a function of how many of their respective members were present. The August 25 majority in favor of firing professors who refused to sign the loyalty oath was small and the vote could have gone the other way as it did earlier. Second, the definition of what was at stake in the decision changed, and this change was clearly presented during that same meeting. Whereas for fifteen months "the battle cry was to purge the University of California of Communists," at the August 25 meeting, being suspected Communists was not the reason given for firing the 32 professors who refused to take the oath. One member of the group in favor of the oath said, "Whether they are Communists or not is now a secondary matter," to which a member of the opposite side replied by stating the new issue more clearly: "It is now a matter of demanding obedience to the law of the Regents." 
With these points clarified, Kantorowicz could hand down his verdict: A divided group cannot claim that non-obedience to rules it adopts using majority rule justifies firing anyone. He substantiates this with two arguments. The first he sums up in a question:

"“Conformity' to whom?" A small, variable majority cannot force obedience to a decision whose content seems to consist in demanding conformity, under pain of heavy sanction, with the views of approximately half of its members. His second argument is that forcing compliance with a faction runs counter to the academic ideals of "'impartial scholarship and free pursuit of truth' which the Regents themselves demand."

In fact, these two arguments are allusive, indirect and probably make too much of the change in the definition of what was at stake as articulated at the August 25 meeting. But once we resituate them in Kantorowicz's text as a whole, we see that they point to two more general arguments that clearly indicate limits to majority rule and the conditions of obligation it generates.

Kantorowicz's first argument is rather obscure as he formulated it. There is no doubt a kind of hiatus between division in a decision-making group with a fluctuating majority and the severity of the sanction incurred by not complying with one of its decisions, but might not this reasoning amount to rejection of majority rule altogether? If the condition of validity for a decision-making rule is that the majority score has to be sufficiently higher than the minority score to ensure that there are no U-turns and that the decision will indeed be carried out, this would mean that simple majority rule ( $50 \%$ of the vote plus one) is never valid and that only a qualified majority could legitimately impose its opinion-and do so all the more easily the higher the qualification threshold. Nonetheless, Kantorowicz does point up a real problem, which in the case of the Board of Regents appears quite spectacular: For nearly two years, it reached contradictory decisions on the loyalty oath requirement, decisions that depended on the presence and absence of oath partisans and opponents. What can majority rule be worth if yesterday's-minority-become-today'smajority can systematically overturn yesterday's majority's decision? It is this question that I examine in the last section of the article, in connection with the relationship between majority rule and deliberation.

But we can already draw a lesson from our observation of voting instability of this sort. If the point of a decision-making rule is to produce a kind of obligation to undertake what was decided - and decided with a minimum of stability - then it is reasonable to conclude that decision reversals due to changes in the majority that are in turn due merely to which members were present and which absent are indeed an anomaly. 
It may even be that if the minority of the day does not obey the same day's majority decision, that is because the conditions have not been met for rendering the normative dimension of majority rule effective. This in turn means that the division of a committee into two stubborn halves is not so much a reason that invalidates majority rule, as Kantorowicz sees it in this case, as an effect of the fact that the conditions that make its use valid have not been met. The Board of Regents could become the arena for a "numerical power struggle" between two groups bent either on imposing or defeating the oath requirement precisely because that requirement called into question the very institution for which the Board is called upon to make decisions.

\section{The majority cannot impact on what unites it to the minority}

Kantorowicz's second argument, the centerpiece of his entire analysis, is as follows: The oath requirement and the firing of refractory professors go against the idea of the University because they abrogate tenure; that is, the protection that usually ensures professors' academic freedom. This is "the fundamental issue." But the connection between this substantive critique-whose worth is independent of the decision-making method used-and the idea that such a decision cannot be made by way of majority rule only becomes clear if we consider the empirical counterexamples he cites to substantiate it:

A professor can be legally dismissed for "gross incompetence," which is not the issue here, or for "moral turpitude." Are we now urged to acknowledge that non-conformity to Regent Neylan (= conformity to Governor Warren) is "moral turpitude"?

The point that the two counterexamples have in common with the case at hand concerns the conditions for inclusion-and therefore exclusion-of a member of the teaching body. Competence and moral rigor are required to fulfill the function of professor. To this the Board of Regents wanted to add a political characteristic: not being a Communist and being willing to swear to it. This point clarifies the difference that, according to Kantorowicz, invalidates the use of majority rule in this particular case. If a committee using majority rule decides to fire a teacher

${ }^{6}$ ERNST H. KANTOROWICZ, THE FUndAMENTAL ISSUE: DOCUMENTS AND MARGINAL NOTES ON THE UNIVERSITY OF CALIFORNIA LOYALTY OATH (1950), pp. 7. 
for incompetence or immorality, that decision concerns the given professor's competence or morality. But it was not a committee using majority rule that determined what qualities faculty members must demonstrate (e.g., competence and morality); the nature of the required qualities had already been established and is constitutive of the University. The committee's legitimate work is to assess whether an individual complies with an already established norm. The Board of Regents did not decide to denounce 32 of the university's professors for belonging to the Communist Party; indeed, the Regents all agreed that there were no grounds for that accusation. Rather, the decision was to establish a political norm that brought into the balance the very definition of what a university and a faculty are. ${ }^{7}$ The entire second part of Kantorowicz's "marginal notes" concerns the nature of the University. He demonstrates in detail how partisans of the oath requirement called into question the academic institution itself, in large part because they were ignorant of its true nature. The Board of Regents cannot legitimately decide on the $50 \%$-plus-one basis to fire professors because that decision would be based on reasons that change the nature of the institution for which they are making decisions, the institution to which the Board majority as well as its minority belong. The majority cannot impact on the nature of what links majority and minority voters, i.e., the institution to which they all belong and for which they are acting together.

What institution and what tie are likely to be affected by such a decision-an institution and a tie that must be preserved in order for majoritarian obligation to be valid? Here we can invoke the reasoning that Jeremy Waldron attributes to Locke: The requirement of submitting to a majority decision no longer applies if that decision imperils the security or goods that motivated group members to enter into association or society. ${ }^{8}$ Waldron then puts the same idea more prosaically yet, to my

\footnotetext{
${ }^{7}$ It should be added that even if the Board had accused the professors of being Communists, that accusation and its effects would have presupposed that not-havingcertain-political-convictions had already been established as a norm and prerequisite for being a professor. This is why it seems to me that Kantorowicz overestimates the power of the change in the definition of the decision made on August 25 for his argument against the validity of majority rule. On the other hand-and the first point surely explains this second one-the redefinition was crucial for the story, because it marked the first defeat of loyalty oath partisans, who clearly could not keep the controversy trained on the communist threat. 8 JEREMY WALDRON, THE DIGNITY OF LEGISLATION (1999), pp. 140-141. Waldron attributes this reasoning to Locke by deduction, attaching the conditions for consent specified in $\S 131$ of the second essay ("no rational creature can be supposed to change
} 
mind, too narrowly: "If I consent to be part of an organization to promote goals $X$ and $Y$, I cannot be bound by that organization's decision to promote some quite different objective Z" (p. 140). It would be preferable to formulate the point less instrumentally, in a way that, while remaining general, steers clear of the fiction of a social pact, thus: The members of any association must submit to the majority's decision only if that decision does not in any way call into question a constitutive feature of the association.

As Waldron points out, the most important point is that there is no automatic requirement to consent. It is not as if majority rule were an agreement which, once made, somehow meant that any and all questions could be decided on that basis. Three features distinguish majority rule from such an agreement:

1) The principle of consent to a majority decision is part and parcel of majority rule; however, effective consent is not granted once and for all but for each decision;

2) Effective consent is granted for reasons;

3) Those reasons concern the ends implied by the decision and the relationship between those ends and the social body or institution in the interests of which the decision is made.

In sum, the minority must consent as long as the decision does not imperil or modify the nature of the group making that decision or the broader collectivity in the name of which that group decides. Majoritarian obligation carries with it a limit to its own relevance or application. ${ }^{9}$

his condition [from the state of nature to civil society] with an intention of being worse") to the role of such consent in explaining the prevalence of majority rule stated in $\$ 96$ of the same essay ("that which acts any community, being only the consent of the individuals of it, and it being necessary to that which is one body to move one way; it is necessary the body should move that way whither the greater force carries it, which is the consent of the majority"). See JOHN LOCKE, TWO TREATISES OF GOVERNMENT (I. Shapiro ed., 2003).

${ }^{9}$ The spread of constitutional democracies, with constitutional courts and procedures for checking the constitutionality of laws, has often gone together with debate on how "non-majority" bodies can limit parliamentary powers. The idea underlying this debate is that parliamentary decisions are an indirect yet legitimate (because majority) expression of the citizens at large. However, the idea that majority rule should always prevail because it is the expression of the People is too simple. Majority rule can prevail if majority decisions do not go against that People. This amounts to saying that the 
This means that counting - noting the numerical result of the votedoes not suffice to define majority rule. Voter equality is the rule, of course, and votes are therefore not weighed. But if "weighing" refers to the idea that there are certain qualitative considerations to be taken into account and that decisions reached should be assessed on the basis of the deliberating body's identity (and therefore that the weight of arguments must be checked), then majority rule presupposes both counting and weighing. Pliny the Younger's remark about the Roman Senate (and not about democracy, as is often affirmed) that votes are counted but not weighed ${ }^{10}$ is true but misleading, as it suggests that use of majority rule means the unfettered control of number.

This point brings us back to the matter of deliberation, because it implies not only that individuals deliberate to determine how they are going to vote also but that they must reflect on the question-especially if consent seems costly to them or if its legitimacy appears doubtful-to ensure that they are indeed required to consent to the voting result.

For the moment, the first general lesson to be learned from the loyalty oath affair is that majoritarian obligation is conditional. Decisions must not call into question that which links together all the given partners. As I see it, there are two distinct ways of thinking about this tie, which I will examine separately in the next two sections. The first is that what unites members of the given society and justifies majoritarian obligation is fairness in satisfying members' wishes and demands; this idea pertains to an order of justice that is strictly distributive. The second is that what unites those members is a social order in which, as participants in a collective decision-making process, they become subordinate parts of a totality or whole.

\section{The Place Of FAIRness}

That majoritarian obligation is conditional may ease some reservations against majority rule. However, it does not resolve the problem that generates the strongest, most frequently leveled criticism, that of persistent minorities. If a numerically inferior subgroup regularly

people (members) that make up the People have to ask themselves what People exactly they constitute in order to be sure that the decisions they make will not trouble what that People is. The idea of constitutional oversight of majority decisions (parliamentary ones, for example) has its source in an elementary reality that is not particular to democracy but to the use of majority rule in general.

${ }^{10}$ PlinY THE Younger, LeTters (Bk. II, Letter XII). 
puts forward proposals or expresses wishes that differ from those prevailing in the rest of the voter group, those wishes or proposals have no chance of attaining majority status. The occurrence of persistent minorities fuels the idea that there is something tyrannical in majority rule.

A good example of this criticism can be found in connection with representation of blacks in American politics in the opening of a book entitled The Tyranny of the Majority. Author Lani Guinier illustrates what she believes is at stake in decision-making rules in democratic societies with a few anecdotes that bring to light the problem and the solution she recommends. One such anecdote concerns choosing which songs will be performed at the senior prom at Brother Rice, a Catholic high school in Chicago:

Each senior was asked to list his three favorite songs, and the band would play the songs that appeared most frequently on the lists. Seems attractively democratic. But Brother Rice is predominantly white, and the prom committee was all white. That's how they got two proms. The black seniors at Brother Rice felt so shut out by the "democratic process" that they organized their own prom. As one black student put it: "For every vote we had, there were eight votes for what they wanted ... [W]ith us being in the minority we're always outvoted. It's as if we don't count". Some embittered white seniors saw things differently. They complained that the black students should have gone along with the majority: "The majority makes the decision. That's the way it works."11

${ }^{11}$ LANI GUINIER, THE TYRANNY OF THE MAJORITY: FUNDAMENTAL FAIRNESS IN REPRESENTATIVE DEMOCRACY (1994), pp. 2-3. Let me clarify that my critique of this interpretation concerns the general value of the example and does not extend to the overall claims of the work, which pertain to black representation in America's legislative bodies; the author puts forward an alternative method for choosing their members. My subject here is majority rule as used to make particular decisions such as which candidate should be offered a job entailing responsibilities. The problem of choosing legislative representatives, for example, is of a different nature because it involves choosing several such representatives; and, in so doing, it raises the question of the relationship between the set of chosen representatives and the diversity of political opinions in the electoral body. To grasp the difference in the nature of the two problems we need only refer to Kelsen's thinking. For Kelsen, majority rule is a pillar of democracy, but he also thinks that a strict proportion rule should be applied in legislative elections so that all opinions are represented in the assembly in proportion to their prevalence in public opinion; on the other hand, the elected legislature itself should decide by way of majority rule. See HANS KELSEN, THE ESSENCE AND VALUE OF DEMOCRACY (N. Urbinati \& C. Invernazzi eds., Brian Graf transl., 2013). On the problem 
For Lani Guinier, this story demonstrates how majority rule can tyrannize the minority group. She and the black students are perfectly right: applying majority rule in this case was unfair. Why? Let us return to the definition of the situation. The questionnaire collected the high school students' wishes as based on their tastes in music. The method for selecting the songs thus aimed to satisfy the greatest number of students. Achieving fairly full correspondence between a student's favorite songs and those that actually get programmed was considered a good, while divergence between the two lists was considered deprivation. From this perspective, the procedure aimed to distribute that good and that evil. In this case, then, the problem was one of fair division. ${ }^{12}$ And majority rule is indeed a poor method for achieving fair division, much less effective than rotation or lottery voting, for example. Guinier's anecdote therefore does offer an example of a mechanical, inappropriate and morally reprehensible use of majority rule.

But her choice of that anecdote is a good example of a frequent flaw in reasoning on collective decision-making; namely, inattention to situation definition and an overly loose idea of what a collective decision is. The situation Guinier chose is one in which majority rule is neither justified nor generally used. The author has confused two types of situations that call for different rules for determining a collective choice: fair division situations on the one hand, collective decision situations on the other. The confusion between the two can also be found in more theoretical writings. Let us briefly consider two examples.

\section{Preferences to satisfy?}

Ben Saunders suggests systematically comparing the advantages and disadvantages of majority rule and lottery voting. ${ }^{13}$ His main argument

of descriptive representation raised by Lani Guinier, see Jane Mansbridge, Should blacks represent blacks and women represent women? A contingent "yes", 61 JOURNAL OF POLITICS 3 (1999), pp. 628-657.

${ }^{12}$ For a synthesis of the literature on this problem see STEVEN BRAMS \& ALAN TAYLOR, FAIR DIVISION: FROM CAKE-CUTTING TO DISPUTE RESOLUTION (1996).

${ }^{13}$ Lottery voting works as follows: 1) after deliberating, participants vote in favor of the option that seems preferable to them; 2 ) the scores define the probabilities of the various options or candidates: for example, an option that wins $40 \%$ of the votes is granted a probability of $40 \%$; 3 ) an option is then drawn at random (lottery). Any option that 
is that majority rule is not systematically superior and that the choice between the two methods should be made case by case. Naturally, he mentions the case of persistent minorities:

If the majority and minority form fluidly on each issue, then we can assume that all individuals will have a greater chance of ending up in the majority than not, so allowing the majority to rule would be both fair and likely to maximise aggregate satisfaction. (...) The contexts in which lottery voting may be suitable are those where some persistent minority know in advance that majority rule will see them lose. In those cases, I think they can reasonably reject majority rule as rigged, rather than fair. ${ }^{14}$

What is remarkable in this passage is that majority rule and lottery voting are assessed in terms of their ability to fairly share out a goodvoter preferences. In his comparative examination, the author is careful to discuss a flaw in the method he is rationally advocating: lottery voting may lead to designating a member of a non-democratic minority or at least of a minority whose values are deeply at odds with those of a wide swath of the population. If for example, the French Republic had used this method in the 2007 presidential election, there is a considerable possibility $(14 \%)$ that Jean-Marie Le Pen (extreme right) or Olivier Besancenot (extreme left) would have become chief of state. And though elections do indeed imply a problem of distributing and satisfying voter preferences, it must be acknowledged that in nearly all cases, extreme right and extreme left voters are persistent minorities treated unfairly by majority rule.

Conscious of the challenge represented for the method he is defending by the chances of success of electoral minorities who have been heavily rejected by a considerable proportion of the rest of the population, Ben Saunders imagines a set of not very convincing safeguards (stronger judicial review, a minimum threshold of votes for being included in the final lottery vote, compulsory public voting to make voters behave responsibly $)^{15}$ but, oddly enough, this does not lead him to imagine elections in any other terms than fairly dividing among electors the

received at least one vote must be accepted if drawn at random, but its chances of becoming the decision are proportionate to the share of votes in its favor.

${ }^{14}$ Ben Saunders, Democracy, Political Equality, and Majority Rule, 121 ETHICS 1 (2010), pp. 169-170.

${ }^{15}$ Ben Saunders, Democracy, Political Equality, and Majority Rule, 121 ETHICs 1 (2010), pp. 171-173. 
chance of having their preference "win."

Mathias Risse, meanwhile, sets out to enhance and strengthen the argument in favor of majority rule. ${ }^{16}$ One of the things an advocate of majority rule must do, he explains, is to find a solid justification for choosing one of two types of methods: preference aggregation methods (including majority rule) and fair division methods (including lottery voting). It is remarkable that in the end he does not put forward any fundamental reason for preferring one method type to the other. Although he emphasized the importance of choosing between the two kinds of methods, he finds out that the fair division methods could rise problems of applicability that majority rule does not suffer. Thus, finally only contingent and empirical considerations, and not a normative evaluation, justify the use of majority rule rather than the use of fair division methods. ${ }^{17}$

Whatever their assessments of the respective values of majority and fair division rules, the three afore-cited authors do have one point in common: they seem to think that these two methods ultimately could apply to the same type of situation. This suggests that they have not grasped a distinction that is not only relevant in general but necessary to understanding the nature and success of majority rule. The missing distinction is between a collective choice made by a collection of individuals whose wishes are to be satisfied and a collective decision also made by a collection of individuals but to accomplish the goals of a collective entity. Elizabeth Anscombe made the same distinction between a group of travellers who have hired a means of collective transportation and then have to collectively choose where they want to go and MPs voting to pass a law. ${ }^{18}$ The latter are not expected to determine how a good gets distributed among them.

\section{The respective weights of contributors}

Before specifying the nature of this contrast, let me give the reader an idea of what I mean by a collective decision or a decision made by a group-i.e., precisely what the afore-cited authors do not take into

${ }^{16}$ Mathias Risse, Arguing for Majority Rule, 2 THE JournAL OF POLITICAL PHILOSOPHY 1 (2004), pp. 41-64.

${ }^{17}$ Mathias Risse, Arguing for Majority Rule, 2 THE Journal OF POLITICAL PHILOSOPHY 1 (2004), pp. 61.

${ }^{18}$ Elizabeth Anscombe, On Frustration of the Majority by Fulfilment of the Majority's Will, 36 ANALYSIS 4 (1976), pp. 161-168.

1 JOURNAL OF INSTITUTIONAL STUDIES 1 (2015) 
account. The most common experience we may have, directly or indirectly, of collective decision-making and practical inquiry into the validity of using majority rule is belonging to a deliberating body or being concerned for some reason by its decisions; e.g., the administrative board of an association, a committee in the institution where one works, a parliament, a city council, and even our experience of citizens voting in general elections. Whatever the modus operandi specific to these different deliberating bodies, whatever the positions and statuses of their members, the way their agendas are organized, the ways they debate and ultimately reach collective decisions, all share three closely related features:

1) In general, individuals acquire the status of member once the deliberating body has been instituted, and that body continues to exist after they cease being a member. The institution time frame seldom coincides with the time frame of member status. Moreover, an individual who joins the body acquires rights, assumes responsibilities and incurs duties, which he loses or is relieved of when he leaves the body. In sum, the role he assumes is linked to the purposes of the collective entity.

2) Decisions are not understood to be made in the interests of members of the deliberating body but in the name of the deliberating body itself and/or the greater authority it may represent or for which it acts. This assertion may be softened in many ways, but at the very least, decisions are not made systematically or strictly in the name of members' immediate interests. What is important here is the validity of two complementary statements: There are many ties between the goods and ends pursued by members and the goods and ends that supposedly orient the deliberating body's decision-making and the way these two sets of goods and ends fit together is usually subjectively and objectively opaque because members do not have precise knowledge of it and because it may be indeterminate.

3) The association, committee, parliament or nation has an environment; its initiatives concern more than the individuals who work together to make decisions for it. These bodies have external surroundings and interlocutors: other associations, committees or institutions within a given political regime, other nations. The relation between an inside and an outside, the aims or functions that connect the two, are also a constitutive component of the deliberating body. 
The institution's time frame, the distinction and fit between collective and individual aims, the polarity between inside and outside - it is these features that enable us to recognize the existence of the collective entity at the heart of a collective decision. These three empirical facts explain how it is that the permanence of the deliberating body is independent of the changing collection of members it comprises (i.e., individuals have the status of member at a given moment and no longer have it at another, and as members, they may or may not be present at meetings). The diachronic identity of the deliberating body is linked to its history, its abilities and functions with regard to its environment, and continuity or change in the aims assigned to it. ${ }^{19}$

With this in mind, let us return to Lani Guinier's story. The situation would have been defined differently if the high school students had been asked what set of songs would have been best for attaining some end in connection with the school; e.g., making it into the best senior prom in Chicago. In that case, the students would have been thought of as stakeholders in the school's collective decision. The procedure might have been the same (collecting each student's three songs), but there would be two differences: 1) in the new situation, the high school would be conceived as a collective entity in relation to its environment, e.g., other high schools, other institutions; 2) the music program would not be decided on the grounds of satisfying students' tastes since they would all be contributors to a collective decision rather than individuals with a right to a share of a good. It would make no sense to apply the fair division method; majority rule could be applied without fear of infringing on the rights of a minority ${ }^{20}$ since the distribution of a good-i.e., "The songs on the program are the ones I chose" - would not be the central problem the procedure is meant to resolve. ${ }^{21}$

${ }^{19}$ In the preceding passage, I have made use of Vincent Descombes' notion of collective entities in general; see, among his other works, VINCENT DESCOMBES, LES EMBARRAS DE L'IDENTITÉ (2013), chap. 4.

${ }^{20}$ It is obviously necessary to come back to this point and provide arguments in favor of majority rule in this case - which I do in the last section of the article.

${ }^{21}$ There are several sources of the tendency to assimilate fair division and collective decision: 1) Both activities involve collective choice understood as the collective selecting of one option out of several; 2) A tendency to abusively extend the distributive nature of some situations to all situations: it does happen that decisions correspond to costs and/or benefits for some proportion of participants, but this does not mean that all collective decisions must necessarily be thought of in terms of distribution; 3 ) There is a perspective from which decision-making is the equal sharing out a good, regardless of what is at stake in the decision. This perspective is at work in liberal justifications of 
There is, however, a concern about fairness that should be operative in any collective decision-making process, and it concerns how much each participant may "weigh" in the decision with regard to the principle justifying his or her participation in that decision. It is important to recall that people partake in collective decision-making on the basis of a particular status. If the principle that justifies participation is the equal sovereignty of each voter, as in our political elections and many committees, then everyone's weight is the same. If, on the other hand, that principle is ownership, as in a general assembly of condominium owners or a company administrative board, then each voter's weight will be proportionate to how much he owns of the building or company for which the decision is being made. Collective decision-making fairness rules therefore concern contributors' respective degrees of influence, not their chances of obtaining the decision they want; they concern the process, not the decision-making result. We may assume that for each participant it is good for his or her individual will to coincide with the collective will, but it is not the job of the collective decision-and, therefore, of majority rule-to share this good out fairly.

$$
\curvearrowright \Delta \alpha
$$

We see then that the question of whether or not majority rule is fair will be formulated in very different terms depending on the way the situation is defined. Majority rule is not justified when what is at stake is dividing up a good among those with a right to a share in it. On the other hand, the question of fairness in a collective decision-making process is determined by participants' weight(s). In the latter case what links those participants is that they all belong to the collective entity in the name of which they decide.

At this point in the argument, the reader will perhaps accept the idea of a difference between fair division and collective decision-making, but she may be less inclined to grant the relevance of the distinction between a collection of individuals and a collective entity. At the very least there

majority rule, the major advocate being Kelsen, but also in our spontaneous view of collective decision-making. It is reasonable to think that for each participant, having her will converge with the collective choice is a good while divergence is an evil. Kelsen, Rae and Przeworski all agree that majority rule is normatively superior because it maximizes the number of participants whose individual will coincides with the collective one (see the last section of this article). If such convergence is a good, then decision rules can indeed be assessed in terms of how fairly they distribute it. 
is a descriptive problem to resolve: How do we get from a description of individual actions to a description of entity actions? The answer to this question will allow me to dissipate the mystery of majoritarian obligation.

\section{IN THE NAME OF A WHOLE}

How can we account at one and the same time for a deliberating body as plural or composite (MPs collectively reaching a decision) and as a totality or whole ("The Parliament has decided thus and such")? And how can we conceive of the fit between the two levels?

\section{The petition model and the deliberating body}

I shall now try to argue why it is necessary to take both types of discourse into account, and suggest instruments useful for doing so, on the basis of the thinking of Jeremy Bentham - a political philosopher who at first glance seems extremely unlikely to serve my purposes. Bentham used his rigorous nominalism to develop path-breaking ideas on what is needed to ensure the proper functioning of political assemblies, and those ideas can be readily applied to all deliberating bodies. ${ }^{22}$ For Bentham, any collective entity - a community, a parliament, etc. - was merely a fiction and the term "collective entity" convenient but misleading as only the individuals composing it could be said to exist. Consequently, no presentation of the way a deliberating body operated could go beyond describing a multiplicity of individual actions. It was on this basis that he put forward a general definition of political bodies, for the purpose of applying it to the English Parliament. Noting the unstable nature of parliamentary assemblies - the members composing the body were never the same from one meeting to another-he concluded that they could not constitute the basis of a political body; instead, such a body was founded on the fact that its members' stated opinions were all identical:

Every declarative act, the expression of an opinion or of a will, beginning by being that of an individual, may finish by being that of a body. "This, says Titius, is what passes in my mind". "This is precisely what passes in mine" may Sempronius equally say. It is, therefore, the power of agreeing in the same

22 JEREMY BeNTHAM, POLITICAL TACTICS (1999). 
intellectual act which constitutes the principle of unity in a body. ${ }^{23}$

Bentham then offers an excellent empirical example of his definition of a political body: a petition. The petition's identity resides in the text expressing a public position, not in the list of signatories; that list may change and indeed grow longer, but the petition will always be the same. On the other hand, if the same set of individuals sign two texts, we will have two different petitions. Bentham acts as if his definition of the political body, perfectly adjusted to the petition, could be applied to deliberating bodies. But the point of his book is to plead the opposite cause; i.e., to flush out all the sources of disorder likely to undermine the proper functioning of an assembly and to unduly benefit a few particularly active, manipulative groups, to the detriment of the others. This is what his treatise aims to avoid:

From that time, strictly speaking, [the assembly] is no longer a political body; all its deliberations will be prepared in secret by a small number of individuals, who will become so much the more dangerous because acting in the name of the assembly they will have no responsibility to fear. ${ }^{24}$

What intervenes here is the idea that the assembly must be preserved as a whole, a notion that does not fit with the definition of assemblies as collections of individuals. If a political body is only such a collection, different each time it convenes and each time constituted by the fact that the aggregate of individuals all have the exact same opinion, what difference will allow for distinguishing an illegitimate, dangerous collection of individuals from a collection more loyal to the assembly? And what indeed, under these conditions, is an assembly in the name of which one can speak rightfully or wrongfully? From a nominalist perspective, we cannot invoke the complete list of elected officials, which could well be fairly stable from one election to the next (leaving aside resignations and deaths), because as Bentham himself notes ${ }^{25}$, decisions are made by sets of MPs that vary each time-i.e., those present at a given assembly meeting.

Moreover, MPs almost always divide up into two or more opposed opinion groups, a fact that capsizes the definition of the political body as a group whose every member declares the same thing. Bentham does

23 JEREMY BENTHAM, POLITICAL TACTICS (1999), pp. 21.

${ }^{24}$ JEREMY BENTHAM, POLITICAl TACTICS (1999), pp. 20.

${ }^{25}$ JeREMY Bentham, POlitical TACTics (1999), pp. 23. 
not seem to have perceived the contradiction between his definition of the political body and his empirical description of how an assembly operates. However, it will not do to invoke a difference between the legitimate acts of an assembly and inappropriate initiatives taken by subgroups of assembly members on the sole basis of a description of the deliberating body in terms of individual acts.

Indeed, what can be called the petition model is completely off the mark here, for what makes a petition a petition is that it expresses a single opinion published as an invariable text whereas the list of signatories to it can vary. Clearly, being of one opinion cannot be the defining criterion of a deliberating body because in deliberating bodies there are at least two opinions. To grasp the reality of deliberating bodies using the petition model, we would have to imagine two competing petitions, but it is not at all clear what would allow one set of signatories to accept that the other had won out and that it should represent a wider group that would encompasses supporters of the two petitions.

In fact, historians have described a kind of collective decision-making that can be grasped on the basis of the petition model: the via scrutinii used by the Dominicans in the thirteenth century. The monks voted to designate the new head of a monastery; if one name won a majority of votes, the minority was asked to join the majority; if the minority agreed to do so, the winner was said to have received unanimous support and what was understood as the real election could then be held. The election, then, was not the vote but rather the solemn declaration made by one of the monks: "I, Brother M, in my name and in that of all the electors present, hereby elect Brother $\mathrm{X}$ as province prior." But if the minority refused to join the majority, the announcement that was the election was different: "I, Brother $\mathrm{M}$, in my name and in that of all those who share my preference, hereby elect Brother X." This declaration could then be followed by another of the same type made by a different monk, $\mathrm{N}$, in the name of all those who preferred Brother Y. This explains how the procedure could generate two "elections" and therefore two "elects." 26 What is remarkable here is that the election could only invoke a single list, the list of all those preferring the given "elect." As with the petition, what we had was a single option - the name of the chosen person - and the list of all those who had chosen him. ${ }^{27}$

${ }^{26}$ Description borrowed from JEAN GAUDEMET, LES ÉLECTIONS DANS L’EGLISE LATINE: DES ORIGINES AUX XVIÈ SIÈCLE (1979), pp. 326-327.

${ }^{27}$ But this means that no real decision was made. Noting the existence of a majority did not amount to reaching a decision but was instead part of a casuistry whose only purpose was to bring the minority around more or less by force, to make it negotiate, or 
In the practice used in monasteries of the time-as in the nominalist approach to the deliberating body, the notion of petitions, the logic of lists - the idea of a connection between a whole and its parts is either missing or makes no sense. On the other hand, in order to suggest the integrity of the assembly and thereby set up an opposition between it and the machinations of a faction, we need to invoke such a whole and the parts that stand in for or represent it. ${ }^{28}$

We shall soon see how this idea of a whole and its parts is constitutive of all collective entities. But first it is important to note how it can be used in assembly practice. Two well-known instruments, which it would be odd to use in a petition, ensure the fit between individual acts and the collective entity; namely, the quorum and the decision rule (the latter usually being majority rule). The first of these connects the plurality of those present to the assembly as a totality or whole; the second connects opinion diversity with the singularity of the decision reached. Bentham here proves a better sociologist than metaphysician: he recommends using both procedures.

\section{Plurality, the whole, and unity}

Quorum and majority rule have the same effect; both transform a numerical fact - a count-into a right. Having a quorum means that those present can act legitimately in the name of the entire assembly rather than being perceived as a faction. Likewise, majority rule resolves the problem of disagreement. The majority is not merely a more numerous faction that imposes its will on another faction receiving fewer votes. Obtaining $50 \%$-of-the-vote-plus-one means that the multiple individuals who have expressed the same wish are in a position to state the will of the institution.

to request outside interlocutors to arbitrate. For a detailed account of one such chaotic appointment process, see Alain Boureau, Les moines anglais et la construction du politique (début du XIIIè siècle), 54 ANNALES: HisTOIRE, SCIENCES SOCIALES 3 (1999), pp. 637-666. For the casuistry of episcopal elections in the same time see JÖRG PELTZER, CANON LAW, CAREERS AND CONQUEST (2008).

${ }^{28}$ On this question we find an approach in terms of lists, PETER GEACH, REFERENCE AND Generality: An ExAMinATION Of SOME MEDIEVAl AND MODERn THEORIES (1962), Chap. 7 , and an approach that involves describing relations between parts and wholes, Vincent Descombes, The InStiTUtions of MEANing: A DEFENSE OF ANTHROPOlOGICAL HOLISM (S.A. Schwartz transl., 2014), Chap. 15. 
What miracle of numbers and limits allows for the shift from an act of force to an act of legitimate decision-making? What marvelous alchemy intervenes (regardless of the practical and/or normative considerations that determined the quorum and majority threshold proportions) to accomplish or enact the shift from fact to right?

These thresholds are neither a miracle nor some marvelous alchemy. They have the effects they do because and as long as participants comply with the rules that guarantee the existence of the institution within which they act. The collective entity for which a decision is made only continues to exist and to be capable of impacting at all on its environment if the plurality of members that act in its name is thought of - and "thinks" of itself-as both a single unit and a totality or whole made up of parts. Those features are complementary. When we think of a deliberating body as entertaining relations with its environment, it appears as a unique individual entity; when we think of it as entertaining relations with the members that comprise it, it appears as a whole.

The quorum and majority rule (or some other decision rule) are perceived as technical conveniences of the sort that virtually all deliberating bodies adopt. Their use is readily detected. On the other hand, we may not generally grasp that such practices presuppose making use of the concepts of whole, part and unity.

To make this clear, let me cite two episodes in the life of the Parlement of Paris, a key institution of the Ancien Régime, an illustration of how plurality on one hand, whole and unity on the other fit together, yet tensely so. Because this deliberating body was structurally engaged in a constant power struggle, its history enables us to perceive more easily what was required for it to survive as an institution.

The political role of the Parlement within the French monarchy was to record laws and decrees produced by the King's Council and in so doing to assess their compliance with existing legislation and the interests of the realm. The Parlement used a decision-making procedure that combined speaking (parler) and voting; the latter stage clearly resembles voting to determine which of two options has majority support. The relations between the monarch and his (or her) Parlement can be roughly summed up thus: the King (or Queen or Regent) had to obtain the Parlement's approval in order for his texts to have the force of law. Given that the King or his counselors had the right to the last word - the renowned lit de justice (bed of justice) on which the King travelled to Parlement to impose his will-he or they regularly expressed impatience and took offense at the time the Parlement took to examine and record royal decrees, not to mention any remonstrances (requests to change or renounce some part of the text) that it might make when it came to 
applying measures decided by King and Council. The monarch therefore tried to exert pressure on the Parlement through various threats and by playing on his alliances within that same institution, also called the Court or the Company. On their side, parliamentarians were of course not elected but either inherited or bought their office; all authority proceeded from the King, whom they were under obligation to serve. By insisting on correcting the King's proposals in the name of their duty to serve the Crown, they exposed themselves to the royal ire and any resulting dangers. ${ }^{29}$

The following is an account of a meeting between the Queen - the mother of Louix XIV, himself a minor at the time-and the most important member of the Parlement that took place immediately after one of the many occasions on which the parliamentary majority made a recommendation that went against the royal will:

\begin{abstract}
Monsieur the First President very humbly implored Her Majesty to grant him an audience and hear the reasons and justifications for the decisions of the Cour de Parlement; to which the Queen replied that she was not complaining about the Presidents, whom she knew were not of the opinion expressed in the decision; and Monsieur the First President replied that the Company was of one and the same mind and could not suffer any separation or division in its resolutions, the justifications of which it implored Her Majesty to hear. ${ }^{30}$
\end{abstract}

This excerpt stages a brief exchange between two major political players that was in fact an episode of tension between two institutions and between the respective roles of monarch and Parlement. Imploring the Queen to hear the Parlement's reasons amounted to a rhetorical ritual: it was the Presidents' role to report to the royal power on the Company's decisions. But clearly this was more than a manifestation of hierarchical deference; it also recalls a crucial component of the monarchy that both united and opposed the interlocutors: the Parlement's role of recording and registering laws and decrees are what distinguished the monarchy

29 See among others JOHN ROGISTER, LOUIS XV AND THE P ARLEMENT OF PARIS, 1737-55 (1995).

30 JEAN LE BOINDRE, DÉBATS DU PARLEMENT DE PARIS PENDANT LA MINORITÉ DE LOUIS XIV, VOL. 1 (1997), pp. 120 (my italics). The exchange occurred on June 16, 1648. This and the following example are drawn from a study of decision modes in the Parlement of Paris that I am currently conducting with Pascaline Costa; my thanks to her for pointing out these excerpts to me. 
from tyranny. ${ }^{31}$

The tension also concerns the "wholeness," the integrity, of the Company, and that is what interests us here. The Queen knew - and said she knew - that the First President was not part of the majority that had voted in favor of an opinion that went against her. But in response to her remark to this effect the First President was quick to assert-almost as if he wished to anticipate, or preclude, any machinations or simply to remain firmly in his Company role-that he was not speaking as a member of the minority but as Parlement spokesman. He retreated as a part in order to speak in the name of the whole.

The asymmetry in resources-authority and power-between the Queen and the First President was such that the latter could only answer the former with what might be called a lesson on the identity of the institution. The only way he could hope to get a hearing for the Parlement's point of view (since it was incumbent on the Queen to take into account what was presented as the Parlement's sole opinion or decision) was by slipping it into an elementary reminder of the fundamental conditionsconditions determined independently of the will of the Parlement and its First President - of the institutions that formed the basis of the monarchy, an institution to which the Queen was necessarily attached. And curiously, on the playing ground of that lesson, the asymmetry between the two protagonists gets reversed. The impersonal reminder by which the First President intervenes in the exchange while effacing himself enables him to give what might be seen as a master's lesson to a pupil who does not know what the institution called a deliberating body is. The pupil only sees what is physically visible: individuals appear to be doing something together. The master teaches her what is possible and what is prohibited, and under what conditions. A given action or utterance by a given person, he explains, precludes a given action or claim; others are made possible on the basis of earlier noted acts and utterances. The rules are as follows:

1) If such a thing as a parliament exists, it speaks with one and only one voice;

2) Though the monarch has the last word, he or she needs a parliament and must listen to its voice and arguments; otherwise he or she is no monarch but a tyrant.

Another episode in the life of this parliament may help us see how

31 Montesquieu, The Spirit OF LAWs (II, 1, A. Cohler, B.C. Miller \& H.S. Stone eds., 1989). 
the concepts of unity and whole fit into a normative order:

With the Company assembled, and before pursuit of the deliberation, Monsieur the First President was conferring in secret with the other presidents of the Cour; they were reminded that it went against the dignity of the Company to be assembled but not to deliberate; upon which Monsieur the First President explained that he had been obliged to take this moment of time to confer with Messieurs the Presidents on a proposal that they would be presenting shortly and that would be to the Company's advantage. To which Monsieur Viole replied that those proposals, whatever they might be, were not to be examined by eight persons, as no one in the Company contributed any less than they [the eight persons] to its dignity. ${ }^{32}$

The presidents of the chamber had failed to follow a procedural rule and were called to order on it. The fact that that rule required the participation of all parliamentarians in the deliberation is not the point. What is of interest to us here is the point cited to justify the rule and the need to comply with it; namely the "dignity" [dignité] of the company. In this context that word means "eminent function." 33

Here again, the specificity of the Parlement of Paris clarifies what is generally implicit in deliberating bodies. Rules were not recorded, procedures were a matter of tradition, so the rules and what justified them had to be recalled every time an explanation was needed for following or not following them. "Dignity" refers to the ideas of function and importance: the Company fulfilled an eminent function in the kingdom. It was therefore important for it to obtain respect not only outside itself, as we have seen, but also internally, namely through members' compliance with its operating rules. Each of the body's members partook of its dignity. Each, therefore, had rights that the other members had to respect as well as duties, namely the duty to follow the procedure that allowed for reaching a decision.

All of this is true of every deliberating body. A deliberating body belongs to a greater society or social group, within which it is granted or grants itself certain purposes and aims; its members have both rights that they can assert and duties they must fulfill. The deliberating body is a normative order and this is what endows its decisions with authority:

32 JEAN LE BOINDRE, DÉBATS DU PARLEMENT DE PARIS PENDANT LA MINORITÉ DE LOUIS XIV, VOL. 1 (1997), pp. 126.

33 This is the first meaning given for "dignité" in the Littré, an authoritative nineteenthcentury French dictionary: "function éminente dans l'Etat ou l'Eglise." 
in and of itself the majority has no authority. Majoritarian obligation presupposes the statutory transmutation of a plurality of individuals into the subordinate parts of a whole. But we still need to grasp why majority rule is preferable to all other possible rules. The answer lies in the relations between the afore-cited parts.

\section{REITERATING DECISION-MAKING PROCESSES}

At this point we can draw the following conclusion: What counts in majoritarian obligation follows not from majority rule but rather from individuals' membership in a deliberating body.

However, we still need to understand why that specific rule and none other makes it possible not only to reach a decision but also to rightfully impose it. We shall first see what makes majority rule suitable for an assembly of equals; then how the rational shaping of majority opinions is a condition of their authority. If body members agree to follow the preferences of a part in the name of the whole, this means that the members of that part are themselves attentive to the purposes of the whole when forging their own preferences in the course of deliberation on the right thing to do.

\section{An assembly of equals}

Two remarkable properties of the majority threshold make its use seem advisable in any situation where two options compete by way of voting: the majority threshold is both more decisive and more egalitarian than any other. The first property was undoubtedly discovered very early on, as it is easy to see that qualified majority rule will not always allow for reaching a decision: if neither of the two options obtains that qualified majority there is no decision. But the second property is not so obvious. Equality was long associated with the procedure of voting itself rather than with majority rule; i.e., the equality requirement has been met if each participant has one and only one vote. In this respect, majority rule is no more egalitarian than unanimity or any other qualified majority threshold, which in turn means that in early modern philosophy, majority rule was seen as preferable only by default. Unanimity was ideal because it was understood to resolve the problem of obligation, but it had to be rejected on practical grounds in favor of majority rule, which, while only "second best," was nonetheless highly efficient as all that is required is an odd number of voters for one option to systematically receive at least $50 \%$ - 
plus-one.

Not until the twentieth century was it discovered that the main flaw in unanimity was not how unlikely it was to occur; this discovery meant that majority rule was simply superior to unanimity on all points. Hans Kelsen demonstrated that majority rule was the only truly egalitarian rule; Bernard Manin that unanimity is useless; and Douglas Rae that it is undesirable. ${ }^{34}$

The first lesson to be learned from these advances in our understanding of decision rules, then, is that majority rule is indeed the procedure that a deliberating body should choose if it wants to reach decisions easily and ensure the perfect equality of its members.

The second lesson follows from a point that the three aforementioned discoveries have in common: they represent a new way of grasping the nature of majority rule. In all earlier, classical thinking on the subjectsay from Pufendorf to Rousseau-the sole approach to justifying a decision rule is in terms of a political body with a problem to resolve or an action to perform and that must reach a decision in order to do so. The question was, What rule will both allow that body to reach a decision and preserve its legitimacy? That question is still present in the thinking of the three twentieth-century authors but it is subordinated to scrupulous examination of the different facets of the relationship between individual and collective wills. For both Kelsen and Manin, this goes together with two indissociable concerns that are quite alien to the earlier thinking: 1) individuals can change their opinion, their preferences are not cast in stone but can be shaped and modified; 2) individuals thus capable of changing their minds may wish to "remake" particular decisions.

Kelsen imagines an individual who has voted with a qualified majority- of $70 \%$ plus one, let us say. After the decision is made, that individual changes his mind; he comes to think that the minority option is preferable. He therefore wants a new decision-making process on the

${ }^{34}$ HANS Kelsen, THE EsSENCE AND VAlue OF Democracy (N. Urbinati \& C. Invernazzi eds., Brian Graf transl., 2013), pp. 7-9; Bernard Manin, On legitimacy and political deliberation, 15 POLITICAL THEORY 3 (E. Stein \& J. Mansbridge transl., 1987), pp. 338-368; Douglas Rae, The limits of consensual decision, 69 AMERICAN POLITICAL SCIENCE REVIEW 4 (1975), pp. 1295-1297. In an earlier article, Douglas Rae mathematically proved Kelsen's discovery that the majority threshold maximizes the number of persons for whom the collective will corresponds to the individual will; see Douglas Rae, Decision rules and individual values in constitutional choice, 63 AMERICAN POLITICAL SCIENCE REVIEW 1 (1969), pp. 40-56. Unfortunately I do not have space here to summarize Rae's demonstration that unanimity does not resolve the problem of obligation. 
same question, but now he is in the minority. The collective will be more likely to align with his new opinion on the second vote if the majority threshold is brought down closer to $50 \%$ plus one. ${ }^{35}$ Kelsen points out not only that simple majority rule maximizes the number of voters whose individual will coincides with the collective will, but also that only this rule gives each voter the same chance of being a pivotal player, a fact later demonstrated by May. ${ }^{36}$

Bernard Manin begins with the fact that participants in a collective decision-making process have not already determined their preferences when that process begins and that those preferences can change. For him, it is not from the ideal of unanimity (with the understanding that majorities are only a kind of substitute for it) that decision legitimacy derives. Unanimity is only necessary for decision legitimacy if we assume that participants have already determined what they want. If instead we take into account the fact that they determine their preferences at least in part during and thanks to deliberation, then the inclusion principle, which is indeed required for a decision to be legitimate, can be satisfied by the fact that all members of the group can participate in the deliberation. Manin also points out that deliberation is what gives the minority a positive status: not only has it been respected in that it has been able to make its arguments heard but also because at the moment the majority decision gets applied, the minority may remind the assembly that another position might have prevailed and that it (the minority) may well be in a position to prevail in the near future. That the decision-making process can be reiterated and the decision changed is part of what justifies the majority principle.

We see that realizing that it is sometimes desirable to revise or change a decision was determinant in discovering the superiority of majority rule for an assembly of equals. But reiterating the decision-making process in order, perhaps, to change the decision is also a threat to the validity of majoritarian obligation.

${ }^{35}$ Let us say that the first decision was reached at precisely the required threshold: $70 \%$ plus one. If this rule remains in effect, the individual in question has to convince $40 \%$ of his fellow members to change their minds as he has changed his-to whom would be added the $30 \%$ minority from the first vote (assuming no one in it has changed their mind). If instead a simple majority were required, he would only have to convince $20 \%$. ${ }^{36}$ Kenneth O. May, A set of independent necessary and sufficient conditions for simple majority decision, 20 ECONOMETRIA 4 (1952), pp. 680-684. 


\section{Numerical power struggle or majoritarian obligation}

We can now return to the aspect of the loyalty oath and of Kantorowicz's analysis that I alluded to above. From February 1950 to November 1951, decisions on the oath requirement were made in the course of seven consecutive Board of Regents meetings. At only one of those meetings, held in April 1950, was there a near-unanimous vote: by 20-1, the Board adopted a proposal that included a modified version of the oath and stipulated that professors refusing to sign it could be heard by an Academic Senate committee. With the exception of this proposal, attesting to a temporary compromise between oath partisans and opponents, all proposals at these meetings aimed to annul the decision taken at the preceding session. Moreover, though the last two of the seven meetings took place after the decision to terminate refractory professors had been overturned by the State of California appeals court (April 1951) and after a change in Board of Regents composition that worked in favor of rescinding the oath requirement, the last vote, which took place in November 1951, was nonetheless a last-ditch attempt by the leader of the pro-oath side to overturn the decision to rescind the oath requirement made the month before. Leaving aside the near-unanimous vote of April 21,1950 , we observe a series of alternating majorities for/against the oath (see Table I):

Table I: Votes on the loyalty oath requirement and the proposal to fire professors refusing to take $i^{37}$

\begin{tabular}{l|c|c|c} 
Dates & $\begin{array}{c}\text { In favor of the } \\
\text { oath }\end{array}$ & Against the oath & $\begin{array}{c}\text { No. of members } \\
\text { present }\end{array}$ \\
\hline $24 / 02 / 1950$ & $\mathbf{1 2}$ & 6 & 18 \\
\hline $31 / 03 / 1950$ & $\underline{10}$ & $\underline{10}$ & 20 \\
\hline $12 / 07 / 1950$ & 9 & $\mathbf{1 0}$ & 19 \\
\hline $25 / 08 / 1950$ & $\mathbf{1 2}$ & 10 & 22 \\
\hline $\begin{array}{l}\text { Partial change in Board } \\
\text { composition }\end{array}$ & - & - & - \\
\hline $19 / 10 / 1951$ & 8 & $\mathbf{1 2}$ & 20 \\
\hline$--/ 11 / 1951$ & 5 & $\mathbf{1 2}$ & 17 \\
\hline
\end{tabular}

37 See the Appendix for a brief account of voting chronology and the main events of the controversy 
In October 1950, when Kantorowicz was writing about the issue, he identified two stable sides within the Board of Regents, 12 members for the oath and 11 against, and he listed the names. ${ }^{38}$ But at no meeting were the entire 23 Board members present, and as we see from Table I, the majority at each session was in large part determined by the game of presences and absences.

That game is determinant more often than we may think. ${ }^{39}$ More importantly, regardless of how frequently it occurs, its possible occurrence brings to light a potential weakness of majority rule. First, the result becomes contingent-i.e., quite strictly dependent-on presences and absences. Second, the decision results from what can be called a "numerical power struggle." At first sight this expression seems solely metaphorical and perhaps nonsensical. To grasp its meaning we have to recall an idea on the nature of majority rule that is occasionally mentioned, usually dismissively: Majority rule is a means of taking into account an existing power balance while avoiding any violence. "There are more of you," say the minority to their opponents, "It's useless to fight because we can foresee the outcome, so we'll just concede that you have won thanks to your numerical and physical superiority." ${ }^{40}$ This idea does not hold up, and it has been rejected several times, namely by Kelsen and more recently by Waldron, for two reasons: a bigger group is not necessarily a stronger group, and above all, might-in this case a favorable power balance-does not make right. However, majority rule does have to produce obligation, which is precisely what a power balance cannot do. The problem is that the second, more powerful argument can easily turn against the majority if yesterday's minority can become today's majority and set out to systematically overturn earlier decisions. Let us look more closely at the argument that force cannot make right, as formulated with particular acuity by Rousseau:

38 See ERNST H. KANTOROWICZ, THE FundAMENTAL ISSUE: DOCUMENTS AND MARGINAL NOTES ON THE UNIVERSITY OF CALIFORNIA LOYALTY OATH (1950), pp. 2.

${ }^{39} \mathrm{~A}$ fact I was able to observe and analyze in a study of the administrative board of one of France's Fonds Régional d'Art Contemporain (a regional-level public fund for purchasing contemporary artworks); see PHILIPPE URFALINO \& CATHERINE VILKAS, LA DELEGATION DU JUGEMENT ESTHÉTIQUE: LES FONDS RÉGIONAUX D'ART CONTEMPORAIN (1995).

${ }^{40}$ Simmel in his excursus sees this as a sort of myth of origin of the majority principle. See Georg Simmel, The Phenomenon of Outvoting, in THE SOCIOLOGY OF GEORG SIMMEL (Kurt H. Wolff transl. and ed., 1964). 
For once force makes right, the effect changes together with the cause; every force that overcomes the first, inherits its right. (...) If one has to obey by force, one need not to obey by duty, and if one is no longer forced to obey, one is no longer obliged to do so. Clearly, then, this word "right" adds nothing to force; it means nothing at all here. ${ }^{41}$

If the reality (i.e., the existing physical power balance) and right coincide, this means there is nothing to prevent right from being overturned: any change in the power balance will change the presumed right. We need only replace "physical superiority" with "numerical superiority" to claim that the obligation produced by majority rule only holds until such time as the minority can transform itself into the majority.

Does the occurrence of an assembly divided into two stubborn halves, each eager to overturn the decisions obtained by the other at the first opportunity, totally undermine the idea of majoritarian obligation? The question seems difficult to answer at first. This type of situation seems quite ordinary, normal, yet there is something troubling in it. By looking at the contrast between it and another case of decision revision we can grasp why that is.

It sometimes happens that the first decision is reconsidered because a relatively high number of majority voters seem to have changed their mind, and when the participants reconvene, a new majority moves to change the option chosen the first time, modifying it or even rescinding it. Some of the Athens Assembly debates recounted by Thucydides involved revising decisions taken at earlier meetings. ${ }^{42}$

In which of the two cases, then-a change in the list of those present or a change in the opinions of the same voters-are the grounds for revision stronger? In both cases participants can only be motivated by their convictions about what should be done. The difference lies in the cause for revising the decision: is it a change in the voter list or has the opinion of some of those who voted with the majority the first time changed in the interim? If we exclude the improbable conjecture of

${ }^{41}$ Jean-Jacques Rousseau, The Right of the stronger, in THE SOCIAL CONTRACT AND OTHER LATER POLITICAL WRITINGS (V. Gourevitch ed. And transl., 1997), pp. 44.

42 The most remarkable example of this is the Mytilenean Debate. Immediately after the Assembly of Athens decided to execute all of Mytilene's adult males, that decision was regretted and a new meeting was called to decide upon a less drastic punishment. THUCYDIDES, THE HISTORY OF THE PELOPONNESIAN WAR (Bk. III, §XXXVI, R. Crawley transl., 2004). 
infinite opinion instability, revisions due to a change in participants' view of a situation promise greater stability. Above all, such revisions seem to us more legitimate because they are the effect of reflection, of learning, whereas revisions due to the game of presences and absences seem merely contingent.

Once again we are confronted with the relationship between majority rule and deliberation, which we are now in a position to discuss.

\section{A rational power for opposites}

For Kelsen and Manin the normative justification of majority rule is closely linked to epistemic considerations. Kelsen points out how acceptance of majority rule goes together with a particular philosophy of knowledge that stands opposed to "absolutist" thinking. Whereas someone who believes he has some special access to truths or values will not be willing to submit to the majority, accepting majority rule means having a "fallibilist" understanding of practical knowledge: ${ }^{43}$

He who only relies on earthly truth and only allows human knowledge to direct social policy can justify the coercion, which the realization of that policy inevitably requires, in no other way than with the assent of at least the majority of those who are supposed to benefit from the coercive order. Furthermore, because the minority is not absolutely wrong, the coercive order must be constructed in such a way that the minority will not be rendered entirely without rights and itself can become the majority at any time.44

The connection between the normative justification of majority rule and the "fallibilist" philosophy of knowledge becomes clear when we recall that the condition for majoritarian obligation is the ever-open possibility that the minority can become the majority. What exactly does this mean? Two types of answers are possible, and they correspond to two

${ }^{43}$ Kelsen uses the term "relativist philosophy," which is misleading in the context of the contemporary debate on relativism. The long note 70 on pp. 97-98 of Hans Kelsen, Foundations of Democracy, 66 ETHICS 1 (1955), pp. 1-101, shows that his position cannot be confused with moral relativism. It seems to me that Kelsen's arguments are closer to John Stuart Mill's fallibilism, namely the latter's argument for respecting minority opinions, though Kelsen does not cite Mill.

${ }^{44}$ Hans Kelsen, The Essence And Value of Democracy (N. Urbinati \& C. Invernazzi eds., Brian Graf transl., 2013), pp. 104 (my italics). 
different ways of justifying majority rule. First, that possibility should be realized tangibly through rotation. An individual who belongs to the minority should be able to expect that she will one day belong to the majority. Kelsen's answer seems consistent with this, i.e., more generally, a justification of majority rule on the grounds that it shares out over time the good defined by the coincidence of individual and collective wills. ${ }^{45}$ But the possibility in question can also reasonably refer not to expected, empirically attested rotation but rather to voters' very exercise of reason. If their choice is determined by practical reasoning and does not correspond to a fixed, rigid preference, then that choice might have been different. This means that the minority option could have been the majority option. Here, then, the "possibility" is what Aristotle called a "rational power for opposites." That power refers to the fact that an agent who uses his reason to determine what action to take is in a position to adopt one or the other of two opposed options. ${ }^{46}$ From this perspective, the legitimacy of majority rule depends on the nature of decision-makers' preference formation. It is because the preferences revealed by voting result from reflection and reasoning, and so could have been different, that the majority opinion can legitimately prevail. In order for participants to be able to agree to allow the majority opinion to become the deliberating body's decision, two closely related conditions must be met. In sum, participants have to be able to assume that

1) the part that will stand for the whole has taken into account that whole in determining its will; i.e., that it has drawn on an acceptable interpretation of the purposes and goals of the deliberating body as the foundation for its practical reasoning;

2) since one or more reasoning processes were what led to the same majority conclusion, that conclusion could have been different and the minority could have been the majority.

If, on the other hand, it appears that a significant segment of majority opinions were not really the result of practical reasoning but instead rigid preferences-rigid because riveted, as it were, to some voter particularity-then there is a chance that those preferences were not

${ }^{45}$ It is this conclusion that Adam Przeworski rightly draws from his reading of Kelsen in Adam Przeworski, Self-Government in Our Times, 12 AnNuAL RevieW Of POLITICAL SCIENCE 71 (2009), pp. 71-92 and ADAM PRZEWORSKI, DEMOCRACY AND THE LIMITS OF SELF-GOVERNMENT (2010).

46 ARIstotle, The Metaphysics (Bk. IX, Chap. 5, 1048, J.H. McMahon transl., 2008). My interpretation here takes a degree of liberty with the text. 
formed by taking into account the common goods and ends of the deliberating body, ${ }^{47}$ in which case those in the minority can reasonably conclude that they had no chance of constituting the majority. If this occurs, they may think that the situation should be redefined. If the issue of the vote is restricted to the possibility of having one's preference win, they can rightfully demand a procedure that will fairly divide up this good, for in such case, majoritarian obligation and the identity and wholeness of the deliberating body have indeed been called into question.

Clearly then, what makes "the majority" a value with more weight than mere numerical superiority is deliberation by individuals.

I therefore subscribe to Bernard Manin's conclusion, though my reasoning process was different than his. Manin sees a closer connection than Kelsen did between the validity of majoritarian obligation and the rational dimension, as his major contribution to thinking on majority rule was to have linked it to deliberation..$^{48}$

It is important to point out that the first strong point of Manin's argument is to have been attentive to the connection between deliberation and decision-reaching. He took into account a phenomenon that distinguishes collective decision-making from other types of collective choice: whether the purpose is to determine what action to take or to select a candidate for a position of responsibility -i.e., a job where he or she will have to initiate actions - collective decision-making presupposes mobilizing reasons; it requires reasoning about what will be good for the collective entity and its purposes. This is why decision-making cannot be disconnected from deliberation, understood as practical reasoning. Moreover, it is because decision-making requires practical reasoning that it makes sense to reiterate decision-making processes: the deliberating body might have deliberated poorly the first time. ${ }^{49}$

${ }^{47}$ This does not mean that voters have to leave aside their own personal ends or interests, as Jane Mansbridge judiciously points out. See Jane Mansbridge, Deliberation and Self-Interest, in DELIBERATIVE DEMOCRACY AND ITS DISCONTENTS (S. Besson \& J.L. Marti eds., 2006), pp. 107-132.

${ }^{48}$ Manin's 1987 article became a reference in the literature on deliberative democracy, which preceded it by several years. That literature (at least when it was coming to prominence) emphasized the value of consensus and so did not seem to recognize that Manin had not disconnected majority decisions from deliberation. See Bernard Manin, On legitimacy and political deliberation, 15 POLITICAL THEORY 3 (E. Stein \& J. Mansbridge transl., 1987), pp. 338-368.

${ }^{49}$ The contrast with random drawing is helpful here. Random drawing is legitimate when the understanding is that reasoning should not intervene in selecting one of several 
In his justification of majority rule, Bernard Manin distinguishes between a decision-making principle and a legitimacy principle. First, majority rule offers the advantage of systematically, unambiguously selecting an option-which is crucial given that decision-making is necessary to the preservation of social unity. Second, the legitimacy of the result is due to the deliberation: if everyone was in a position to participate in that deliberation, then the majority decision is legitimate. Once again, the weight of Manin's argument bears on deliberation inclusiveness; the rejection of unanimity has left its mark here. It seems possible to me, complementarily, to found the legitimating nature of deliberation more firmly still on its rationality.

\section{CONCLUSION}

There are, then, three conditions that must be met in order for a majority decision reached by an assembly of equals to obligate all of its members. First, the assembly cannot be merely a collection of individuals but a deliberating body, i.e., a collective entity. Second, the issue involved in the decision cannot call into question members' attachment to that collective entity. And third, preference aggregation is not enough to identify a legitimate majority; preferences have to result from deliberation, and this is what makes it reasonable to assume that those preferences might have been different. If preferences are rigid or do not result from deliberation in which members keep in mind the purposes and goals of the deliberating body, then the collective decision reached is more like fair division, and majority rule is no longer relevant. I am in no way claiming that on the innumerable occasions that decisions are reached by majority rule these three conditions have all been met. In some cases it is habit that determines the use of majority rule, in others interest and the hope of a future victory. It is also possible that the imperatives of efficiency and equality, combined with the idea that at least half of participants plus one will be satisfied, are enough to ensure acceptance of majority rule. But if a new institution is reflecting on what decisionmaking procedures to adopt or a group contests the use of previously adopted procedures, it is my conviction that the above-defined conditions of majoritarian obligation are what may relevantly and rightfully be cited to justify using or rejecting majority rule.

options. And assuming there was no cheating or machinations, it makes no sense to reiterate a random drawing process. 


\section{REFERENCES}

ADAM PRZEWORSKI, DEMOCRACY AND THE LIMITS OF SELF-GOVERNMENT (2010).

Adam Przeworski, Self-Government in Our Times, 12 AnNuAl RevieW OF Political SCIENCE 71 (2009).

Alain Boureau, Kantorowicz: StORIES OF A Historian (S.G. Nichols \& G.M. Spiegel transl., 2001).

Alain Boureau, Les moines anglais et la construction du politique (début du XIIIè siècle), 54 ANNALES: HISTOIRE, SCIENCES SOCIALES 3 (1999).

ARISTOTLE, THE METAPHYSICS (J.H. McMahon transl., 2008).

Ben Saunders, Democracy, Political Equality, and Majority Rule, 121 ETHICS 1 (2010).

Bernard Manin, On legitimacy and political deliberation, 15 POLITICAL THEORY 3 (E. Stein \& J. Mansbridge transl., 1987).

Chaim Perelman \& Lucie OlBReChts-TyteCA, THE NeW Rhetoric: A TREATY OF ARGUMENTATION (J. Wilkenson \& P. Weaver transl., 1969).

Douglas Rae, Decision rules and individual values in constitutional choice, 63 AMERICAN POlitical SCIENCE REVIEW 1 (1969).

Douglas Rae, The limits of consensual decision, 69 AMERICAN POLITICAL SCIENCE REVIEW 4 (1975).

Elizabeth Anscombe, On Frustration of the Majority by Fulfilment of the Majority's Will, 36 ANALYSIS 4 (1976). 
ERNST H. KANTOROWICZ, THE FUNDAMENTAL ISSUE: DOCUMENTS AND MARGINAL NOTES ON THE UNIVERSITY OF CALIFORNIA LOYALTY OATH (1950).

Georg Simmel, The Phenomenon of Outvoting, in The Sociology OF GeORG SIMMEL (Kurt H. Wolff transl. and ed., 1964).

Hans Kelsen, Foundations of Democracy, 66 ETHICs 1 (1955).

Hans Kelsen, The Essence and Value of Democracy (N. Urbinati \& C. Invernazzi eds., Brian Graf transl., 2013).

Jane Mansbridge, Deliberation and Self-Interest, in DeLIBERATIVE

DEMOCRACY AND ITS DisCONTENTS (S. Besson \& J.L. Marti eds., 2006).

Jane Mansbridge, Should blacks represent blacks and women represent women? A contingent "yes", 61 Journal OF POlitics 3 (1999).

JEAN GAUDEMET, LES ÉLECTIONS DANS L'EGLISE LATINE: DES ORIGINES AUX XVIÈ SIÈCLE (1979).

Jean-Jacques Rousseau, The Right of the stronger, in THE SOCIAL CONTRACT AND OTHER LATER POLITICAL WRITINGS (V. Gourevitch ed. And transl., 1997).

JeAN Le BoindRe, DÉBATS DU PARLEMENT DE PARIS PENDANT LA MINORITÉ DE LOUIS XIV, VOL. 1 (1997).

Jeremy Bentham, Political Tactics (1999).

JEREMY WALDRON, THE DigNity OF LEGISLATION (1999).

JOHN LOCKE, TWO TREATISES OF GOVERNMENT (I. Shapiro ed., 2003). 
JOHN Rogister, LOUIS XV AND THE PARLEMENT OF PARIS, 1737-55 (1995).

Jörg Peltzer, CANON LaW, CAREers AND ConQuest (2008).

Kenneth O. May, A set of independent necessary and sufficient conditions for simple majority decision, 20 ECONOMETRIA 4 (1952).

LANI GUINIER, THE TYRANNY OF THE MAJORITY: FUNDAMENTAL FAIRNESS IN REPRESENTATIVE DEMOCRACY (1994).

Mathias Risse, Arguing for Majority Rule, 2 The Journal OF POLITICAL PHILOSOPHY 1 (2004).

Montesquieu, The Spirit of Laws (A. Cohler, B.C. Miller \& H.S. Stone eds., 1989).

PETER GEACH, REFERENCE AND GENERALITY: AN EXAMINATION OF SOME MEDIEVAL AND MODERN THEORIES (1962).

PhiLIPPE URFALINO \& CATHERINE VILKAS, LA DELEGATION DU JUGEMENT ESTHÉTIQUE: LES FONDS RÉGIONAUX D'ART CONTEMPORAIN (1995).

PLINY THE YOUNGER, LETTERS (Bk. II, Letter XII).

Stéphanie Novak, Majority Rule, 9 PHILOSOPHY COMPASS 10 (2014).

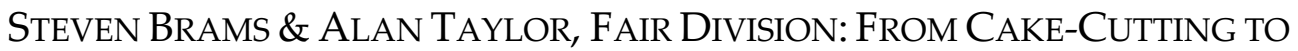
DiSPUTE RESOLUTION (1996).

Thucydides, The History of the Peloponnesian WaR (R. Crawley transl., 2004).

VINCENT DESCOMBES, LES EMBARRAS DE L'IDENTITÉ (2013). 
Vincent Descombes, The InStitutions of MeAning: A Defense OF ANTHROPOLOGICAL Holism (S.A. Schwartz transl., 2014).

\section{APPENDIX}

University of California Board of Regents votes on the loyalty oath ${ }^{50}$

- February 24, 1950: adoption of Regent Neylan's proposal by 12-6: if the loyalty oath is not signed by June 30, professors refusing to sign will be fired ("sign or get out" policy).

- March 31, 1950: the proposal to annul the February 24 decision results in a tie vote, $10-10$.

- April 21, 1950: a less drastic oath proposal, including the right of refractory professors to a hearing before an Academic Senate committee, is adopted 21-1.

- July 21, 1950: President Sproul's proposal not to fire the 39 professors still refusing to sign is adopted 10-9.

- August 25, 1950: the July 21 decision is invalidated 12-10: professors refusing to sign will be fired. 8 agree to sign; the other 31 are fired.

- August 31, 1950: the fired professors file a lawsuit

- April 6, 1951: the Court of Appeal rules against the Board of Regents.

- October 19, 1951: the partially recomposed Board of Regents votes $12-8$ to rescind the loyalty oath requirement.

${ }^{50}$ This information is available at

$<$ http://sunsite.berkeley.edu/uchistory/archives exhibits/loyaltyoath/symposium/docs i mages.html $>$. 
- November 1951: Regent Neylan, leader of the pro-oath requirement group, fails 12-5 to reverse the October 19 decision.

- October 17, 1952: the State Supreme Court upholds the appeals court ruling.

The Conditions for Majoritarian Obligation: Majority Rule and Deliberative Body As Condições para a Obrigação Majoritária: Regra Majoritária e Corpo Deliberativo Submitted: 2015-11-19

Accepted: 2015-12-14 